\title{
BMJ Open Overuse of diagnostic tools and medications in acute rhinosinusitis in Spain: a population-based study (the PROSINUS study)
}

Francesca Jaume, ${ }^{1,2}$ Llorenç Quintó, $^{3,4}$ Isam Alobid, ${ }^{1,2,5}$ Joaquim Mullol ${ }^{1,2,5}$

To cite: Jaume F, Quintó L, Alobid I, et al. Overuse of diagnostic tools and medications in acute rhinosinusitis in Spain: a population-based study (the PROSINUS study). BMJ Open 2018:8:e018788. doi:10.1136/ bmjopen-2017-018788

- Prepublication history for this paper is available online. To view these files, please visit the journal online (http://dx.doi. org/10.1136/bmjopen-2017018788).

Received 7 August 2017 Revised 16 0ctober 2017 Accepted 23 November 2017

Check for updates

${ }^{1}$ Unitat de Rinologia i Clínica de l'Olfacte, Servei d'Otorinolaringologia, Hospital Clinic, Universitat de Barcelona, Barcelona, Spain

${ }^{2}$ Immunoal.lèrgia Respiratòria Clínica i Experimental, Institut d'Investigacions Biomèdiques August Pi i Sunyer (IDIBAPS), Barcelona, Spain

${ }^{3}$ Institut de Salut Global de Barcelona (ISGlobal) de Recerca en Salut Internacional de Barcelona (CRESIB), Barcelona, Spain

${ }^{4}$ Centro de Investigación Biomédica En Red en Epidemiología y Salud Pública (CIBERESP), Barcelona, Spain

${ }^{5}$ Centro de Investigación Biomédica En Red en Enfermedades Respiratorias (CIBERES), Barcelona, Spain

Correspondence to Professor Joaquim Mullol; jmullol@clinic.cat

\section{ABSTRACT}

Objectives Acute rhinosinusitis (ARS) has a high incidence. Diagnosis is clinical, and evolution is mostly self-limited. The aim of this study was to describe the sociodemographic characteristics and use of diagnostic tools and medications in patients with ARS.

Design This is a prospective observational study in reallife clinical practice.

Setting Patients with clinical diagnosis of ARS $(n=2610)$ were included from ear, nose and throat clinics in Spain. A second visit at resolution was done.

Participants Patients were classified according to the duration of symptoms: viral ARS ( $\leq 10$ days), postviral ARS ( $>10$ days, $\leq 12$ weeks) and chronic rhinosinusitis ( $>12$ weeks).

Main outcome measures Sociodemographic characteristics, symptoms, disease severity, quality of life (Sino-Nasal Outcome Test-16), used diagnostic tools and medications, and the management performed by primary care physicians (PCPs) and by otorhinolaryngologists (ORLs) were assessed.

Results Of the patients $36 \%$ were classified as having viral ARS, $63 \%$ postviral ARS and $1 \%$ as chronic rhinosinusitis. Working in a poorly air-conditioned environment was a risk factor (OR: $2.26,95 \% \mathrm{Cl} 1.27$ to 4.04) in developing postviral ARS. A higher number of diagnostic tools (rhinoscopy/endoscopy: $80 \%$ vs $70 \%$; plain X-ray: $70 \%$ vs $55 \%$; CT scan: $22 \%$ vs $12 \% ; P<0.0001$ ) were performed in postviral than viral cases. PCPs performed more $X$-rays than ORLs $(P<0.0001)$. Patients, more those with postviral than viral ARS, received a high number of medications (oral antibiotics: $76 \%$ vs $62 \%$; intranasal corticosteroids: $54 \%$ vs $38 \%$; antihistamines: $46 \%$ vs $31 \%$; mucolytic: $48 \%$ vs $60 \% ; \mathrm{P}<0.0001)$. PCPs prescribed more antibiotics, antihistamines and mucolytics than ORLS $(\mathrm{P}<0.0068)$. More patients with postviral than viral ARS reported symptoms of potential complications $(1.5 \%$ vs $0.4 \%$; $\mathrm{P}=0.0603$ ). Independently of prescribed medications, quality of life was more affected in patients with postviral (38.7 \pm 14.2 vs $36.0 \pm 15.3 ; P=0.0031)$ than those with viral ARS. ARS resolution was obtained after 6.04 (viral) and 16.55 (postviral) days, with intranasal corticosteroids being associated with longer (OR: $1.07,95 \% 1.02$ to 1.12 ) and phytotherapy with shorter (OR: $0.95,95 \% \mathrm{Cl} 0.91$ to 1.00 ) duration.

\section{Strengths and limitations of this study}

- This is a real-life prospective study that provides physicians' real approach to the management of acute rhinosinusitis in their daily practice in Spain.

- The high number of patients included in the study makes the results highly extensible to the general population.

- Following the European Position Paper on Rhinosinusitis and Nasal Polyps classification criteria makes this study adequate for international guidelines.

- The study population cannot be considered a random sample, so the results have been interpreted in terms of association, avoiding any interpretation in terms of causality.

- The management performed by primary care physicians and otorhinolaryngologists cannot directly be compared as they treat the same patients but in different time of disease.

Conclusions There is a significant overuse of diagnostic tools and prescribed medications, predominantly oral antibiotics, by PCPs and ORLs, for viral and postviral ARS

\section{INTRODUCTION}

Rhinosinusitis is an inflammatory process of the paranasal sinuses with high prevalence in clinical practice ${ }^{1}$ and a significant impact on quality of life (QoL). ${ }^{2}{ }^{3}$ Acute rhinosinusitis (ARS) is mainly an inflammatory disease, usually caused by a viral infection, although other processes such allergic rhinitis, anatomical abnormalities, nasal polyps, tobacco smoke or nasal decongestant abuse can constitute predisposing factors. ${ }^{1}$ Viral ARS (common cold) is usually self-resolved and accounts for most of ARS cases. ${ }^{4}$ Postviral ARS occurs as a perpetuation of the inflammatory condition, even when the viral agent has gone. ${ }^{5}$ Only a small percentage of the latter $(0.5 \%-2 \%)$ actually leads to acute 
bacterial rhinosinusitis. ${ }^{67}$ The incidence of ARS is very high, with adults having between two and five common cold episodes per year, ${ }^{8}$ while the incidence of postviral ARS has been reported to be 3.4 cases per 100 inhabitants/year. ${ }^{9}$ Orbital, osseous or intracranial complications may occur, but their incidence is very low (about three cases per million people). ${ }^{10}$

The diagnosis of ARS is based on the clinical history of a sudden onset of nasal symptoms (nasal congestion/obstruction/blockage, rhinorrhoea/postnasal drip, facial pain/ pressure, and/or reduction/loss of smell) supported by physical examination. ${ }^{1}$ Microbiological or imaging studies are not required, ${ }^{11} 12$ with imaging being indicated when symptoms that suggest complications appear. ${ }^{1}$

The goals of ARS treatment are to provide symptomatic relief, accelerate time of remission and prevent complications. Although antibiotics have traditionally been the treatment most often indicated for ARS, there is no evidence that antibiotics are significantly better than placebo in viral (common cold) and postviral ARS. ${ }^{13}$ In fact, a number of bacterial ARS cases have been resolved without antibiotics at all. ${ }^{1415}$ Furthermore, the use of antibiotics does not prevent complications. ${ }^{10}$ Indeed, their overuse can lead to a number of side effects and to an increase of antibiotic resistance. ${ }^{16}$ In the last two decades several studies have demonstrated that the addition of intranasal corticosteroids (INS) to antibiotics, or even INS in monotherapy, may provide an excellent option to treat postviral ARS. ${ }^{17} 18$ Accordingly, the European Position Paper on Rhinosinusitis and Nasal Polyps (EPOS) 2012 recommended symptomatic relievers (analgesics, saline serum and decongestants) for viral/common cold cases, INS for postviral cases, and the addition of oral antibiotic for bacterial/complicated cases or well-established complications. ${ }^{19}{ }^{20}$ Recent studies have shown that selected herbal medicines (phytotherapy) may constitute an additional medical option to treat viral/postviral ARS. ${ }^{21-24}$ However, a number of very commonly used medications such as mucolytics, antihistamines, probiotics or vitamin $\mathrm{C}$ have not shown any evidence of efficacy in ARS. ${ }^{1}$

The objectives of the PROSINUS study (PROspective epidemiological study about the diagnosis and therapeutic management of Acute RhinoSINUsitis in otorhinolaryngology clinics in Spain) were (1) to describe and compare the diagnostic tools and therapeutic medications used by primary care physicians (PCPs) and otorhinolaryngologists (ORLs) to manage viral or postviral ARS in Spain; (2) to assess the risk factors leading to postviral ARS; and (3) to assess the evidence of the efficacy of those medications most often used to decrease disease duration and prevent complications in patients with viral or postviral ARS.

\section{METHODOLOGY}

\section{Study design, participants and setting}

The PROSINUS study was a prospective, real-life and descriptive study that analysed a cohort of patients
( $\mathrm{n}=2610)$ with acute ARS in Spain. Patients were recruited by ORLs $(n=284)$ throughout Spain and classified as suffering from viral (common cold) or postviral ARS based on the EPOS criteria. Each ORL represented $9.2 \pm 1.8$ patients (range $1-11$ ).

To define and classify rhinosinusitis, we used the definitions provided by the EPOS consensus. ${ }^{25}$ ARS was clinically defined by a sudden onset of two or more symptoms, one of which should be either nasal blockage/obstruction/congestion or anterior/posterior nasal discharge. Additional symptoms could be facial pain/pressure and/ or reduction/loss of smell. Three different phenotypes of ARS were defined. Viral ARS (common cold) was defined as the presence of symptoms of rhinosinusitis for less than 10 days, postviral ARS was defined as symptoms lasting for $>10$ days and $<12$ weeks, and chronicity when symptoms lasted for $\geq 12$ weeks.

\section{Inclusion criteria}

Patients of both gender, $\geq 18$ years old, and those who come to see the ORL with symptoms consistent with the clinical diagnosis of viral/postviral ARS according to the EPOS criteria were included in the study. ${ }^{25}$

\section{Exclusion criteria}

Patients with exacerbations of diagnosed chronic rhinosinusitis (CRS), with clinical suspicion of bacterial ARS (severe cases with fever $>38^{\circ} \mathrm{C}$ or unilateral severe pain), or patients not able to do follow-up visits or with a high risk of dropout were excluded.

\section{Study visits}

Patients were included between January 2007 and March 2008. Visit 1 was done at inclusion, while visit 2 was done after 2-4 weeks of inclusion. Where patients still had symptoms at visit 2, visit 3 was performed after 12 weeks of inclusion.

\section{Patients' involvement}

Participants were involved in the study on the basis of daily clinical practice. Patients did not participate in the design of the study.

\section{Ethics}

All patients signed the informed consent.

\section{Measurements and outcomes}

At visit 1, the sociodemographic and anthropometric characteristics, duration of symptoms (days), severity of disease, QoL (Sino-Nasal Outcome Test-16 (SNOT-16)), diagnostic tools used, and medications prescribed before inclusion by PCPs were recorded. The general health status prior to and during the disease was also recorded. At visit 2, the duration of episode (number of days), symptoms addressing potential complications, diagnostic tools used and medications prescribed between visits 1 and 2 by ORLs, severity of disease, and QoL (SNOT-16) were also recorded. Where visit 3 was required (based on no 


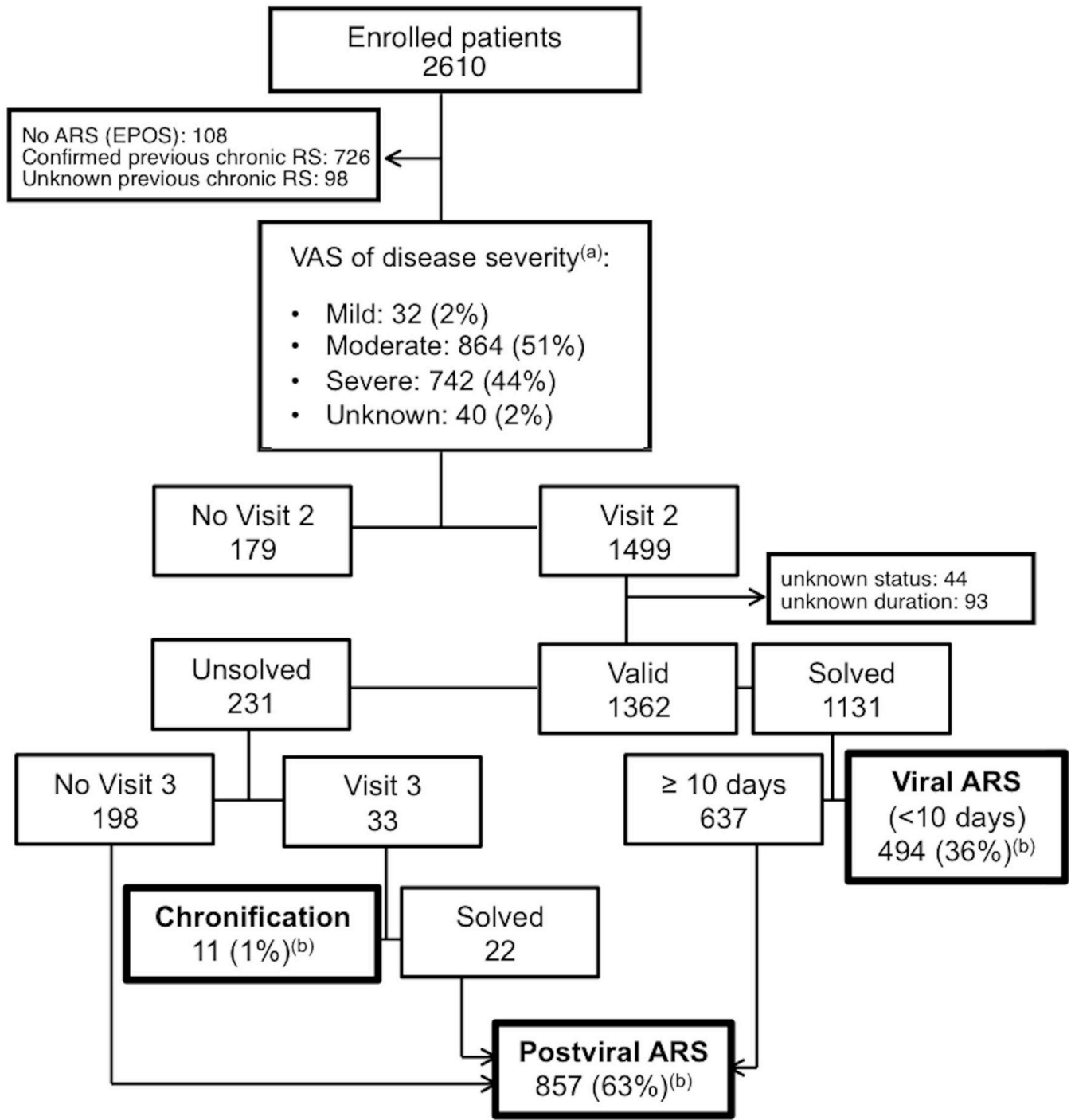

Figure 1 Flow chart of participants in the PROSINUS study (PROspective epidemiological study about the diagnosis and therapeutic management of Acute RhinoSINUsitis in otorhinolaryngology clinics in Spain). Two phenotypes for ARS and one for CRS were analysed: patients with viral ARS/common cold (36\%), postviral ARS (63\%) and CRS (1\%). VAS, visual analogue scale. ${ }^{a} \%$ refers to patients selected at visit $1(n=1678) ;{ }^{b} \%$ refers to patients considered valid at visit $2(n=1362)$. ARS, acute rhinosinusitis; CRS, chronic rhinosinusitis; EPOS, European Position Paper on Rhinosinusitis and Nasal Polyps; RS, rhinosinusitis; VAS, visual analogue scale.

resolution at visit 2), the time of disease resolution or chronification was recorded.

\section{Demographic characteristics}

At visit 1 the following characteristics were recorded: age (years), gender, area of residence (rural, <2000 inhabitants; semirural, 2000-10 000 inhabitants; and urban, >10000 inhabitants), education level (no education or unfinished, primary or secondary education, and higher education or college), workplace environment (proper air-conditioned, poorly air-conditioned, outdoor work, unemployed), social and family circumstances (living as part of a family or in a partnership, single, living in an institution or residence, or living in shared housing), and home environment (well air-conditioned, airy).
Use of diagnostic tools

We recorded the use of anterior rhinoscopy or nasal endoscopy (to assess oedema, congestion or mucopurulent secretion from the middle meatus), imaging techniques (X-ray, CT scan) and microbiological cultures (culture of nasal secretions). This information was recorded at visits 1 and 2 in order to know the tests performed before (by PCPs) and after (by ORLs) the inclusion in the study.

\section{Prescription of medications}

Prescribed medications, either recommended (antibiotics, INS, nasal saline irrigation, nasal decongestants, phytotherapy) or non-recommended (antibiotics, antihistamines, mucolytics) by the EPOS consensus to treat ARS, were recorded at visits 1 and 2 . 
Table 1 Sociodemographic characteristics of acute rhinosinusitis (ARS) study population

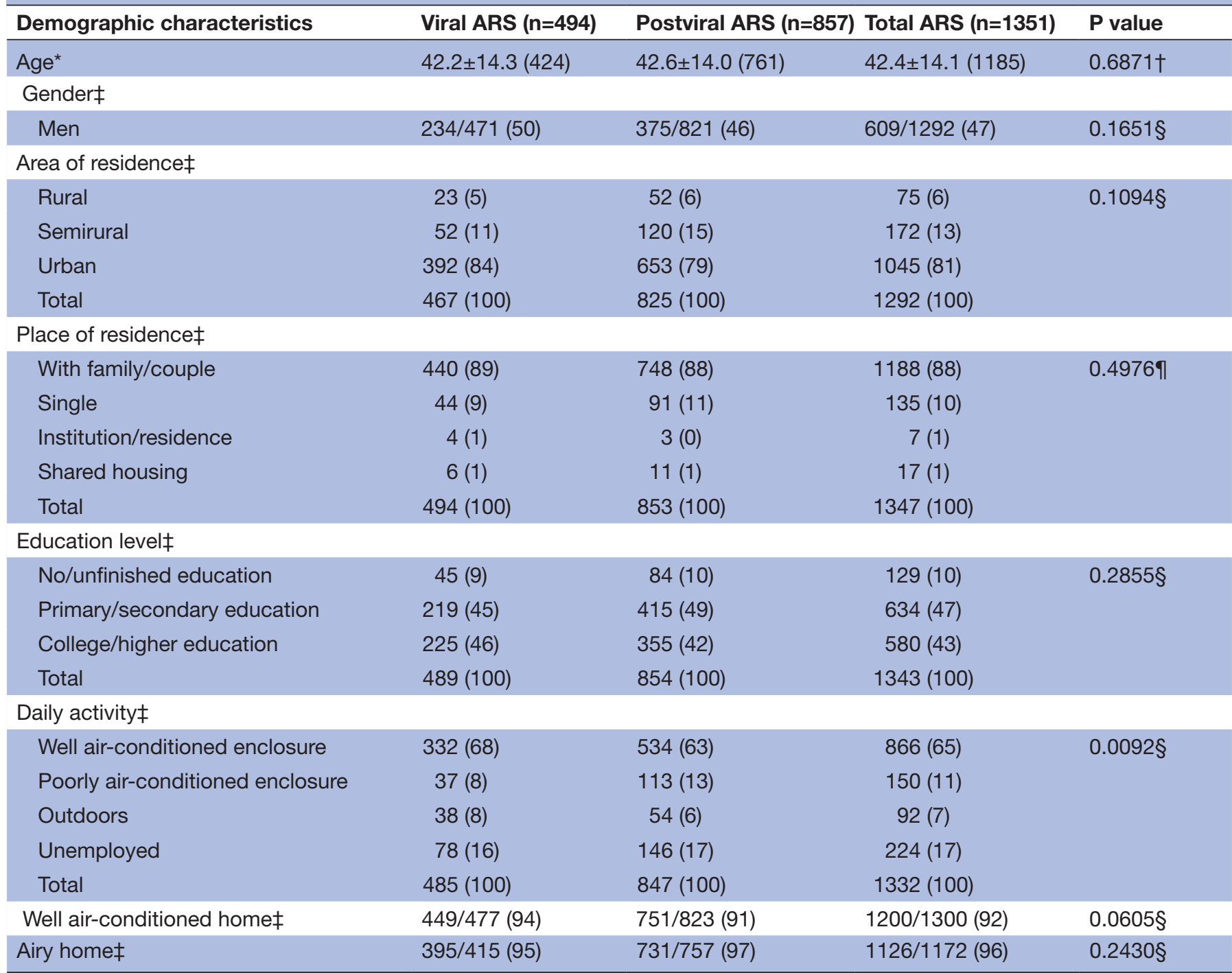

${ }^{*}$ Arithmetic mean $\pm \mathrm{SD}(\mathrm{n})$.

†Student's t-test.

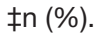

$\S \chi^{2}$ test.

IFisher's exact test.

\section{Episode duration and disease severity}

Duration of symptoms (days) was recorded at visits 1 and 2 , and at visit 3 when needed. Severity was assessed at visits 1 and 2 using a visual analogue scale (VAS, $0-10 \mathrm{~cm})^{1}$ after answering the question how troublesome are your symptoms of rhinosinusitis?' ( 0 , not troublesome, to 10 , worst imaginable). Disease severity was assessed using a VAS $(0-10 \mathrm{~cm})$ and classified as mild (VAS $0-3 \mathrm{~cm})$, moderate $($ VAS $>3-7 \mathrm{~cm})$ or severe $($ VAS $>7-10 \mathrm{~cm}) .{ }^{126}$

\section{QoL and health status}

The SNOT-16 questionnaire was used to assess the impact of disease and its treatment on the QoL at both visits 1 and 2. Each of the 16 items was scored from 0 (not affected) to 5 (extremely affected). The overall score runs from 0 (better QoL) to 80 (worst QoL). The general health status prior to and during the disease was recorded using a VAS $(0-10 \mathrm{~cm})$.

\section{Disease complications}

Instead of recording the presence of complications, the study recorded the presence of symptoms linked to complications, as stated by the EPOS guidelines. ${ }^{25}$ Orbital symptoms (palpebral oedema, orbital pain, diplopia, exophthalmos, decrease in visual acuity), neurological symptoms (meningeal symptoms, neurological deficit) and frontal symptoms (frontal oedema, severe frontal pain) were assessed. In addition, other sinonasal signs and symptoms of a potentially different disease involved were also recorded (unilateral symptoms, bleeding, crusts, lacrimation and conjunctiva hyperaemia, or cacosmia). 
Table 2 Frequency of symptoms in viral/postviral acute rhinosinusitis (ARS)

\begin{tabular}{lccc}
\hline & $\begin{array}{l}\text { Viral ARS } \\
(\mathbf{n}=494)\end{array}$ & $\begin{array}{l}\text { Postviral ARS } \\
(\mathbf{n = 8 5 7 )}\end{array}$ & P value \\
\hline Total, N (\%) & $494(100)$ & $857(100)$ & \\
\hline $\begin{array}{l}\text { Nasal } \\
\text { obstruction* }\end{array}$ & $481 / 493(98)$ & $829 / 857(97)$ & $0.3847 \dagger$ \\
\hline $\begin{array}{l}\text { Rhinorrhoea* } \\
\text { Facial pressure/ }\end{array}$ & $464 / 490(95)$ & $800 / 854(94)$ & $0.4482 \dagger$ \\
pain* $^{*}$ & $370 / 485(76)$ & $653 / 848(77)$ & $0.7659 \dagger$ \\
\hline Loss of smell* & $275 / 470(59)$ & $533 / 847(63)$ & $0.1148 \dagger$ \\
\hline
\end{tabular}

${ }^{*}$ Number of cases and proportion within group (\%). $\dagger \chi^{2}$ test.

\section{Data management and statistical analysis}

Study size

This was an observational study without a specific hypothesis as the main objective. Therefore, the sample size was determined by logistical and cost reasons rather than by analytical criteria.

The sociodemographic characteristics, nasal symptoms, use of diagnostic tools, prescribed medications, disease severity and QoL were compared between patients with viral (common cold) and postviral ARS. Differences in quantitative measures were evaluated by Student's t-test for independent groups, and differences in qualitative measures were assessed with the $\chi^{2}$ or Fisher's exact test as appropriate. The improvement in patient's QoL (SNOT16) between visits 1 and 2 was evaluated by Student's t-test for paired groups.
Logistic regression models were estimated to assess the associations with postviral ARS using viral ARS as the reference group. The relationships between treatments (medication) and disease duration, QoL at visit 2 and the risk of complications were also assessed. These associations were evaluated by linear regression using the duration and the total score of SNOT-16 in logarithmic scale, and by logistic regression for the complications assessment. Multivariate regression models were estimated by a backward selection procedure using 0.05 as significance level for removal from the model. All regression models were adjusted for the study group (viral and postviral ARS). Additionally, regression models to evaluate associations between medication and duration, or medication and complications, were also adjusted for severity at recruitment, whereas models to evaluate associations between medication and QoL at visit 2 were adjusted for QoL at visit 1 . Interactions between treatments were also assessed. Statistical analysis was performed using Stata V.14.

\section{RESULTS}

\section{Demographic characteristics}

From the initial 1678 patients included at visit 1, 1499 (89\%) completed visit 2, with 1362 patients being considered valid for the study (figure 1). Patients were classified into three groups according to the duration of symptoms of rhinosinusitis: $36 \% \quad(n=494)$ had viral ARS (common cold) with a mean duration of 6.0 days (95\% CI 5.9 to $6.2), 63 \%(\mathrm{n}=857)$ had postviral ARS with a mean duration of 16.5 days (95\% CI 15.8 to 17.3$)$, and $1 \%(\mathrm{n}=11)$
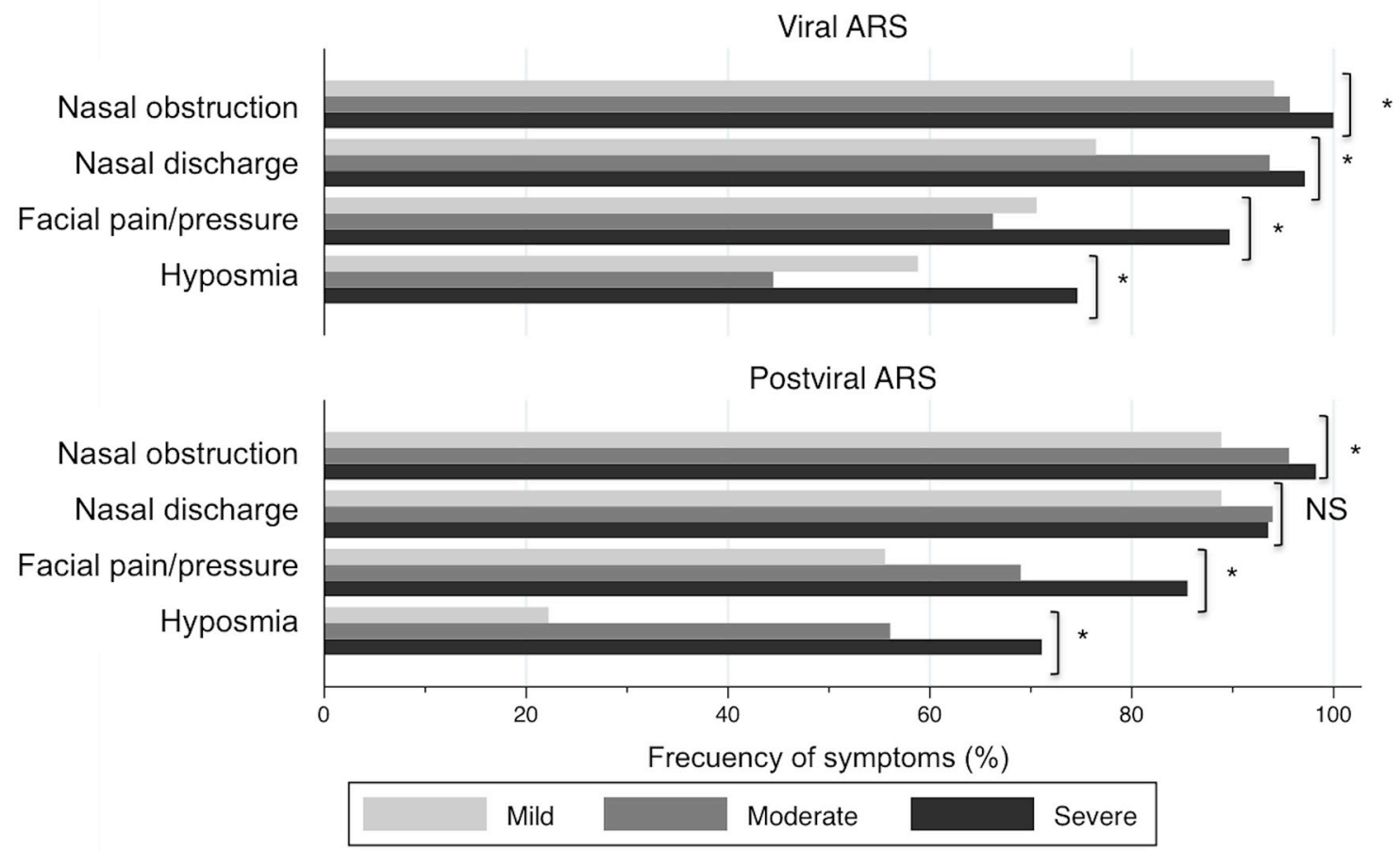

Figure 2 Frequency of symptoms in patients with acute rhinosinusitis (ARS). Bars represent the frequency (\%) of individual sinonasal symptoms in each level of severity for both viral and postviral ARS. Reported frequency of symptoms was always higher in the highest severity level. ${ }^{*} \mathrm{P}<0.05$; NS, not significant. 


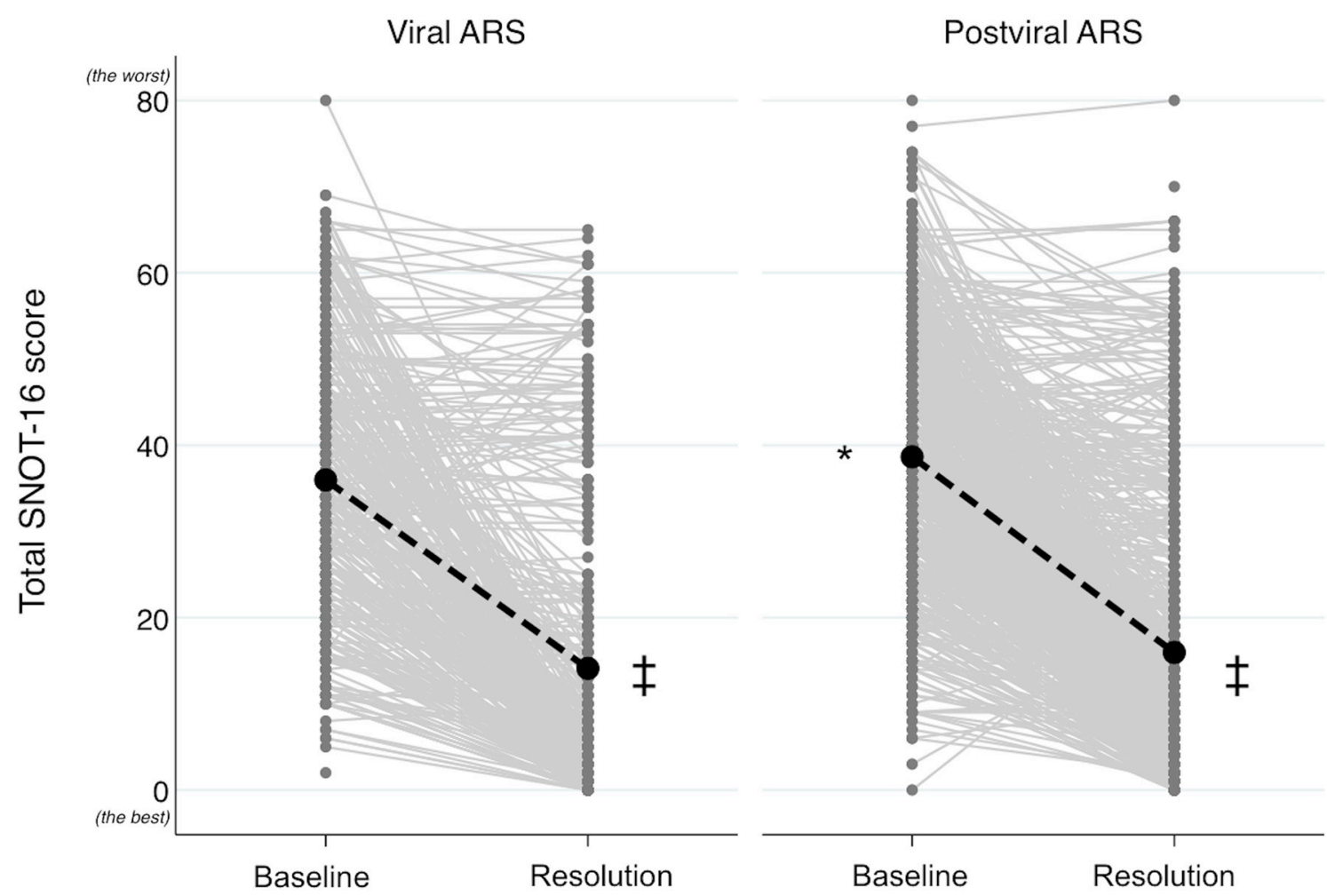

Figure 3 Quality of life (SNOT-16) in patients with ARS. Changes in the individual values (solid lines) and in the average values of each group (dashed lines). At baseline, SNOT-16 score was more affected $\left({ }^{*} \mathrm{P}<0.05\right)$ in postviral than in viral ARS. SNOT-16 score significantly improved $(\ddagger \mathrm{P}<0.05)$ after disease resolution, with no differences between both ARS phenotypes. ARS, acute rhinosinusitis; SNOT-16, Sino-Nasal Outcome Test 16.

had chronic symptoms (CRS). Patients with CRS were excluded from this analysis, and therefore the sample size for analysis was 1351 patients (36\% with viral and 63\% with postviral ARS). By definition, all patients with viral ARS were cured before 10 days. From those with postviral ARS, $74.3 \%$ of episodes were resolved before visit 2, and $25.7 \%$ in the time between visits 2 and 3 (figure 1 ).

More women (53\%) than men participated in the study, with a similar ratio applying to both viral and postviral ARS sample groups. Both groups were also homogeneous with regard to weight, height or ethnicity. Most patients $(81 \%)$ lived in an urban environment, with no differences between disease groups (table 1). With regard to workplace, most patients with either viral $(68 \%)$ or postviral $(63 \%)$ ARS worked in a well air-conditioned environment. Patients working in a poorly air-conditioned environment were significantly higher in postviral $(13 \%)$ than viral $(8 \%)$ ARS $(\mathrm{P}=0.0092)$. Half of the patients $(46 \%)$ reported a history of ARS episodes, without differences between groups.

\section{Nasal symptoms}

Nasal congestion/obstruction/blockage (98\%) and anterior/posterior nasal discharge $(95 \%)$ were the most frequent symptoms of ARS, followed by facial pressure/ pain $(77 \%)$ and reduction/loss of smell (60\%). No differences were found between patients with viral and postviral ARS (table 2). By excluding nasal discharge in the postviral ARS group, the frequency of symptoms was however significantly higher $(\mathrm{P}<0.05)$ when disease severity increased, and this was more relevant for hyposmia and facial pressure/pain in postviral ARS (figure 2).

\section{Disease severity}

Severity by VAS for postviral ARS was slightly higher $(7.13 \pm 1.48 \mathrm{~cm})$ than forviral ARS $(6.98 \pm 1.60 \mathrm{~cm})$, although this was not statistically significant. The general health status (VAS) during the disease episode was also similar in viral $(5.45 \pm 1.89 \mathrm{~cm})$ and in postviral $(5.59 \pm 1.89 \mathrm{~cm})$ ARS, but significantly affected when compared with the general health status they had retrospectively, before the episode $(8.85 \pm 1.40 \mathrm{~cm}$ and $8.67 \pm 1.76 \mathrm{~cm}$, respectively).

When comparing viral and postviral ARS, all three levels of severity were similar (mild: $2.65 \pm 0.57 \mathrm{~cm}$ vs $2.72 \pm 0.57 \mathrm{~cm}$; moderate: $6.11 \pm 0.97 \mathrm{~cm}$ vs $6.09 \pm 1.00 \mathrm{~cm}$; and severe: $8.36 \pm 0.60$ vs $8.35 \pm 0.64$ ). In addition, no differences were found between viral and postviral ARS in general health status (VAS) in the three severity levels, either before (retrospective) or during the disease.

\section{QoL (SNOT-16)}

At visit 1, the SNOT-16 global score was worse in postviral $(38.7 \pm 14.2 ; \mathrm{P}=0.0031)$ than in viral ARS $(36.0 \pm 15.3)$. In addition, a higher SNOT-16 score was strongly related to a higher disease severity degree in both viral and postviral ARS $(\mathrm{P}<0.0001)$. At visit 2 , the SNOT-16 global score significantly improved compared with visit 1 for both postviral $(15.9 \pm 15.9 ; \mathrm{P}<0.0001)$ and viral $(14.1 \pm 17.2$; 


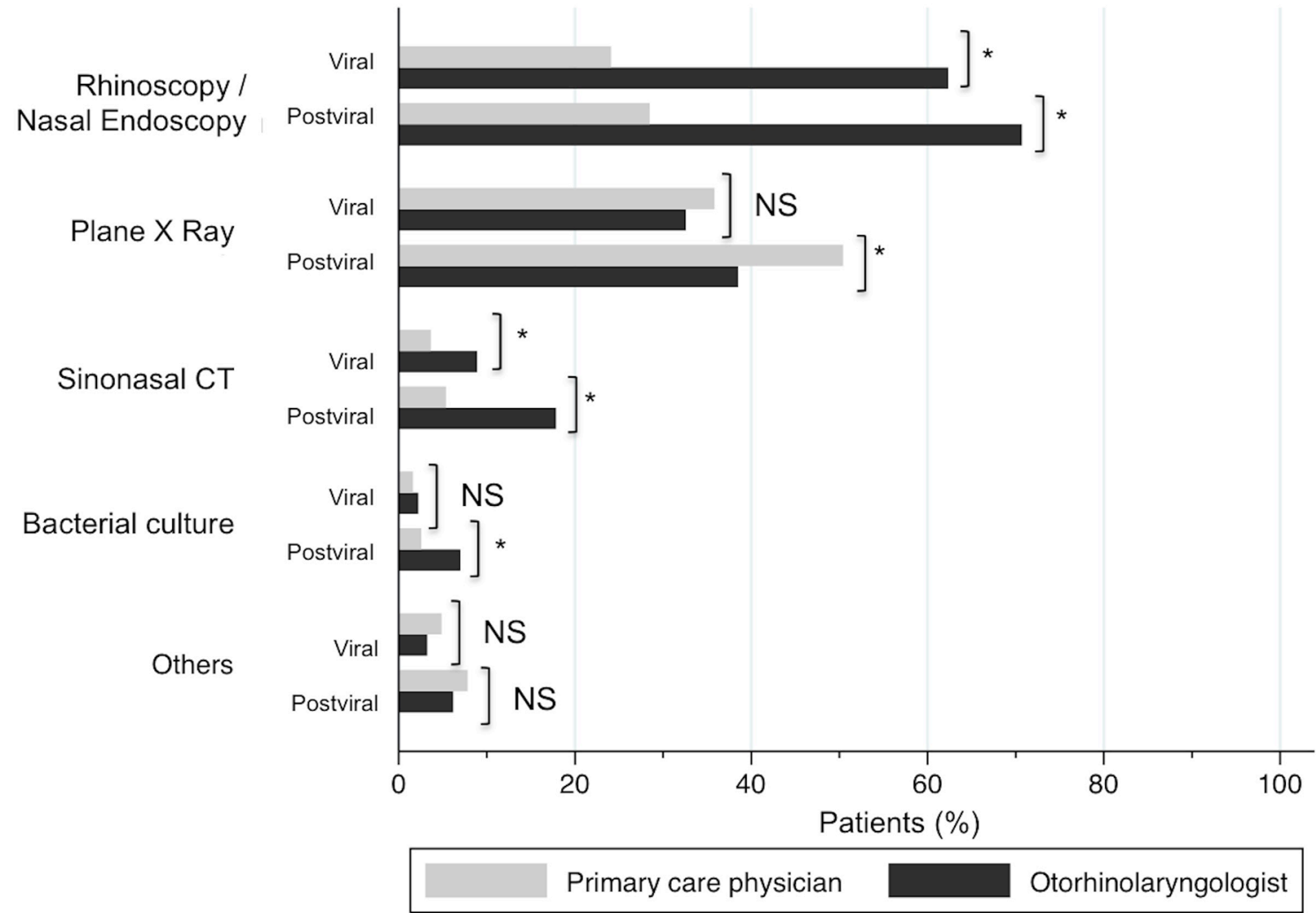

Figure 4 Diagnostic tools performed in patients with acute rhinosinusitis. Percentage of patients undergoing different diagnostic tools, for both viral and postviral acute rhinosinusitis, recommended by either primary care physicians or otorhinolaryngologists. ${ }^{*} \mathrm{P}<0.05$; NS, not significant.

$\mathrm{P}<0.0001)$ ARS. No significant differences $(\mathrm{P}=0.0726)$ between viral and postviral groups were found for the SNOT-16 score (figure 3 ).

\section{Diagnostic tools}

Overall, including all tests conducted before and after patients were recruited for the study, the diagnostic tools most frequently performed were anterior rhinoscopy/ nasal endoscopy (76\%), X-ray (64\%), CT scan (18\%) and microbiology cultures $(7 \%)$, with all of them being more frequent $(\mathrm{P}<0.0002)$ in postviral than in viral ARS (figure 4). PCPs performed more X-ray ( $45 \%$ vs $36 \%$; $\mathrm{P}<0.0001)$ than ORLs, who performed more rhinoscopy/ endoscopy (68\% vs $27 \%$; $\mathrm{P}<0.0001)$, CT scans $(15 \%$ vs $5 \% ; \mathrm{P}<0.0001)$ and microbiology cultures $(5 \%$ vs $2 \%$; $\mathrm{P}<0.0001)$. With regard to disease severity, the performance of X-ray increased with higher levels of severity in postviral $(\mathrm{P}=0.0045)$ but not in viral $(\mathrm{P}=0.0606)$ ARS. In contrast, the performance of CT scan increased with higher severity levels in viral $(\mathrm{P}=0.0024)$ but not in postviral ARS $(\mathrm{P}=0.2631)$.

\section{Medications}

In viral and postviral ARS, the most frequently prescribed medications were oral antibiotic (62\% vs $76 \%)$, topical steroids ( $38 \%$ vs $54 \%$ ), antihistamines ( $31 \%$ vs $46 \%$ ), nasal decongestants (38\% vs $48 \%$ ), mucolytics (48\% vs $60 \%$ ), nasal saline ( $40 \%$ vs $54 \%$ ) and nasal phytotherapy ( $41 \%$ vs $46 \%$ ). All drugs were more frequently prescribed in patients with postviral than with viral ARS $(\mathrm{P}<0.0006$ for all comparisons), except for nasal phytotherapy ( $\mathrm{P}=0.1413$ ) (figure 5).

There were only a few patients $(3 \%)$ who did not receive any treatment, while most of the patients with ARS received more than one medication. Based on the EPOS recommendations, oral antibiotics were incorrectly prescribed in $62 \%$ of patients with viral ARS (common cold), while only $54 \%$ of patients with postviral ARS were treated with INS (table 3).

In addition, PCPs prescribed more oral antibiotics ( $53 \%$ vs $39 \%$; $\mathrm{P}<0.0001)$, antihistamines $(26 \%$ vs $22 \%$; $\mathrm{P}=0.0068)$, nasal decongestants ( $34 \%$ vs $18 \% ; \mathrm{P}<0.0001)$, mucolytics $(45 \%$ vs $21 \% ; \mathrm{P}<0.0001)$ and intranasal saline $(34 \%$ vs $25 \%$; $\mathrm{P}<0.0001)$ than ORLs. However, ORLs prescribed more nasal phytotherapy (39\% vs $9 \%$; $\mathrm{P}<0.0001)$ and showed a tendency to prescribe more INS (30\% vs 26\%; $\mathrm{P}=0.0721$ ) than PCPs (figure 5).

With regard to disease severity, antibiotics and mucolytics were more frequently prescribed in severe cases of both viral and postviral ARS ( $\mathrm{P}<0.0225$ for all comparisons), while antihistamines were more prescribed in severe viral ARS $(\mathrm{P}=0.0040)$, and nasal decongestants $(\mathrm{P}=0.0408)$ in severe postviral ARS.

No significant association was found between medication and QoL (SNOT-16 score) or the risk of complications at visit 2. Interactions between treatments were also assessed, although none of them showed a statistically significant difference. 


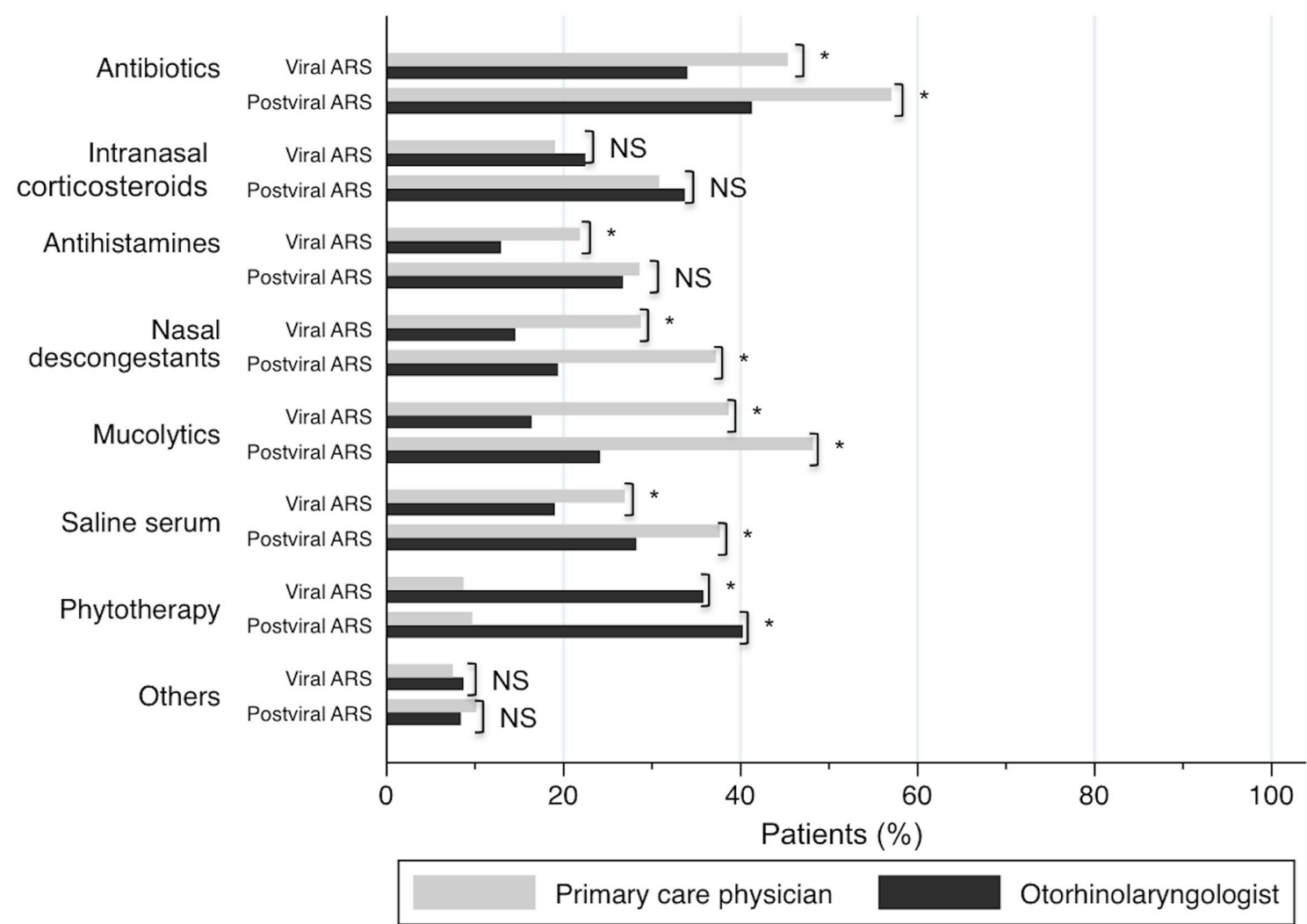

Figure 5 Prescribed medications in patients with acute rhinosinusitis (ARS). Percentage of patients being treated with different medications, for both viral and postviral ARS, prescribed by either primary care physicians or otorhinolaryngologists. ${ }^{*}<<0.05$; NS, not significant.

\section{Disease complications}

More patients with postviral (1.5\%) than viral ARS $(0.4 \%)$ had signs or reported symptoms potentially linked to rhinosinusitis complications, such us ophthalmic, neurological or frontal $(\mathrm{P}=0.0603)$ complications. In addition, there were patients who reported other unusual signs and symptoms (5.6\% in postviral and 3\% in viral ARS) that could potentially be linked to a different diagnosis (table 4). No differences were found when comparing the degree of disease severity.

\section{Factors associated with disease duration}

All population characteristics were analysed to identify factors associated with postviral ARS development. Table 5 shows the crude estimates for ORs using viral ARS as a reference group. In the multivariate analysis we found that working in a poorly air-conditioned enclosure was the only factor significantly associated with developing postviral ARS (OR: 2.26, 95\% CI 1.27 to 4.04).

The analysis of associations between medication and duration, adjusted for type of ARS (viral/postviral) and severity at baseline, showed a longer duration of the episode in patients who took nasal decongestants, saline solutions, antibiotics or INS than in those who did not. According to multivariate analysis, phytotherapy (mainly Cyclamen europaeum, $C E$ ) was related to shorter duration (OR: $0.95,95 \%$ CI 0.91 to $1.00, \mathrm{P}=0.0480$ ), while INS was related to longer duration (OR: 1.07, 95\% CI 1.02 to 1.12, $\mathrm{P}=0.0048)$.

\section{DISCUSSION}

The following were the most significant findings of the PROSINUS study: (1) ARS is mostly a self-limited disease, with only $1 \%$ of chronification; (2) working in a poorly air-conditioned environment was a risk factor for common cold to develop into postviral ARS; (3) both PCPs and ORLs performed a high number of non-indicated diagnostic tools, mainly plain X-ray; (4) ORLs and especially PCPs prescribed a large number of non-recommended medications, with antibiotics being the most significant, followed by mucolytics and antihistamines; (5) INS was less frequently prescribed by ORLs and even less so by PCPs; and (6) there was an association between prescribed INS and a longer duration of ARS, and prescribed phytotherapy $(C E)$ and shorter episodes of disease.

In the present study only $1 \%$ of chronification was found, suggesting that most ARS cases tend to be cured independently of the prescribed treatment. Spontaneous cure with no treatment has been identified in $80 \%$ of patients with ARS. ${ }^{27}$ Working in a poorly air-conditioned environment was the only identified risk factor (OR: 2.26) in developing postviral ARS. Previous studies have suggested the importance of other factors such as contact with people with upper respiratory complaints, ${ }^{28}$ winter months (January to March) having a risk factor (OR: 2.9) to develop ARS compared with July to September, ${ }^{29}$ allergic rhinitis developing in postviral ARS (OR: 4.4) compared with healthy controls, ${ }^{30}$ and active ${ }^{31}$ and passive $^{32}$ smoking. In our study the most prevalent symptoms, 
Table 3 Frequency of recommended combined medications in ARS

\begin{tabular}{|c|c|c|c|c|}
\hline Recommended medications & Viral ARS $(n=494)$ & Postviral ARS ( $\mathrm{n}=857)$ & Total ARS $(n=1351)$ & Postviral ARS $(n=857)$ \\
\hline No treatment* & $27(5)$ & $20(2)$ & $47(3)$ & $0.0025 \dagger$ \\
\hline \multicolumn{5}{|l|}{ Antibiotic* } \\
\hline $\mathrm{AB}$ (total) & $308(62)$ & $648(76)$ & $956(71)$ & $<0.0001 \dagger$ \\
\hline$A B$ alone & $13(3)$ & $6(1)$ & $19(1)$ & $0.0037 \dagger$ \\
\hline $\begin{array}{l}\text { AB in combination } \\
\text { (except with CS) }\end{array}$ & $137(28)$ & $261(30)$ & $398(29)$ & $0.2905 \dagger$ \\
\hline \multicolumn{5}{|l|}{ Intranasal CS* } \\
\hline Topical CS (total) & $188(38)$ & $463(54)$ & $651(48)$ & $<0.0001 \dagger$ \\
\hline Topical CS alone & $1(0)$ & $1(0)$ & $2(0)$ & $1.0000 \ddagger$ \\
\hline $\begin{array}{l}\text { Topical CS in combination } \\
\text { (except with } \mathrm{Ab} \text { ) }\end{array}$ & $29(6)$ & $81(9)$ & $110(8)$ & $0.0204 \dagger$ \\
\hline \multicolumn{5}{|l|}{ Phytotherapy* } \\
\hline Phytotherapy (total) & $205(41)$ & $391(46)$ & $596(44)$ & $0.1413 \dagger$ \\
\hline Phytotherapy alone & $20(4)$ & $9(1)$ & $29(2)$ & $0.0002 \dagger$ \\
\hline $\begin{array}{l}\text { Phytotherapy in combination } \\
\text { (except with } \mathrm{AB} \text { or } \mathrm{CS} \text { ) }\end{array}$ & $39(8)$ & $46(5)$ & $85(6)$ & $0.0654 \dagger$ \\
\hline \multicolumn{5}{|l|}{ Antibiotic + intranasal CS* } \\
\hline AB+topical CS alone & $12(2)$ & $4(0)$ & $16(1)$ & $0.0013 \dagger$ \\
\hline AB+topical CS in combination & $146(30)$ & $377(44)$ & $523(39)$ & $<0.0001 \dagger$ \\
\hline \multicolumn{5}{|l|}{ Saline solutions * } \\
\hline Saline solutions (total) & $197(40)$ & $462(54)$ & $659(49)$ & $<0.0001 \dagger$ \\
\hline Saline solutions alone & $9(2)$ & $4(0)$ & $13(1)$ & $0.0193 \ddagger$ \\
\hline Saline solutions in combination & $188(38)$ & $458(53)$ & $646(48)$ & $<0.0001 \dagger$ \\
\hline $\begin{array}{l}\text { Other combinations without } A B \text {, } \\
\text { intranasal CS or phytotherapy* }\end{array}$ & $70(14)$ & $52(6)$ & $122(9)$ & $<0.0001 \dagger$ \\
\hline Mucolytics* & $235(48)$ & $515(60)$ & $750(56)$ & $<0.0001 \dagger$ \\
\hline Antihistamines* & $154(31)$ & $396(46)$ & $550(41)$ & $<0.0001 \dagger$ \\
\hline Nasal decongestants* & $190(38)$ & $412(48)$ & $602(45)$ & $0.0006 \dagger$ \\
\hline
\end{tabular}

*Number of cases and proportion within group (\%).

$+\chi^{2}$ test.

‡Fisher's exact test.

$A B$, antibiotic; ARS, acute rhinosinusitis; CS, corticosteroids.

in both common cold and postviral ARS, were nasal congestion (98\%) and discharge (95\%), followed by facial pressure/ pain $(77 \%)$ and smell loss $(60 \%)$. Although the presence of nasal symptoms was biased by inclusion criteria, facial pressure/pain and smell loss were highly associated with severe ARS. In a French study done by PCPs, similar findings were reported in patients with acute maxillary sinusitis. ${ }^{2}$ Despite the EPOS guidelines ${ }^{1}$ stating that the diagnosis of ARS is mainly clinical (based on symptoms) and supported by nasal examination (anterior rhinoscopy or nasal endoscopy), in our study, many ORLs and especially PCPs did not perform nasal examination (68\% and $27 \%$, respectively) in patients with ARS. Plain X-ray has proven to have poor sensitivity and specificity $^{33}$ and is not recommended in the diagnosis of ARS. ${ }^{35}$ Since Gwaltney et $a l^{36}$ reported that CT scans show sinus opacity in most patients $(87 \%)$ with common cold, this imaging technique is only recommended in complicated cases. ${ }^{11}$ The present study shows however that physicians from Spain performed a high number of plain X-ray and CT scan in postviral ARS (70\% and 22\%, respectively) but also in common cold (55\% and 12\%, respectively), with plain X-ray predominantly being carried out by PCPs, and CT scan by ORLs. These practices were not related to suspected complications since the frequency of symptoms suggesting complications was very low $(0.4 \%$ in common cold and $1.5 \%$ in postviral ARS).

Although VAS has been validated to assess CRS severity, ${ }^{125} 26$ our study has been the first to use it to assess ARS severity. Interestingly, VAS score was similar in both viral and postviral ARS, suggesting that disease severity is not associated with the duration of disease. Patients with severe ARS have more smell loss, more facial pain and more impact on QoL than patients with moderate and mild ARS. Moreover, plain X-ray was more often indicated and antibiotics more generally 
Table 4 Frequency of unusual symptoms and symptoms suggesting a complication of acute rhinosinusitis (ARS)

\begin{tabular}{|c|c|c|c|c|c|}
\hline & & $\begin{array}{l}\text { Total ARS } \\
(n=1351)\end{array}$ & $\begin{array}{l}\text { Viral ARS } \\
(n=494)\end{array}$ & $\begin{array}{l}\text { Postviral ARS } \\
(\mathrm{n}=857)\end{array}$ & $P$ value \\
\hline \multirow{6}{*}{$\begin{array}{l}\text { Unusual symptoms } \\
\text { (consider different } \\
\text { diagnosis)* }\end{array}$} & Total & $49(3.6)$ & $12(2.4)$ & $37(4.3)$ & $0.0738 \dagger$ \\
\hline & Unilateral symptoms & $8(0.6)$ & $2(0.4)$ & $6(0.7)$ & 0.7179 \\
\hline & Bleeding & $30(2.2)$ & $8(1.6)$ & $22(2.6)$ & 0.2549 \\
\hline & Crusts & $10(0.7)$ & $2(0.4)$ & $8(0.9)$ & 0.3419 \\
\hline & $\begin{array}{l}\text { Lacrimation and conjunctiva } \\
\text { hyperaemia }\end{array}$ & $13(1)$ & $3(0.6)$ & $10(1.2)$ & 0.3950 \\
\hline & Cacosmia & $2(0.1)$ & $0(0)$ & $2(0.2)$ & 0.5358 \\
\hline \multirow{15}{*}{$\begin{array}{l}\text { Symptoms suggesting } \\
\text { a complication* }\end{array}$} & Total & $15(1.1)$ & $2(0.4)$ & $13(1.5)$ & $0.0603 \dagger$ \\
\hline & Orbital symptoms & & & & \\
\hline & Total & $9(0.7)$ & $1(0.2)$ & $8(0.9)$ & $0.1673 \ddagger$ \\
\hline & Palpebral oedema & $6(0.4)$ & $1(0.2)$ & $5(0.6)$ & 0.4246 \\
\hline & Exophthalmos & $0(0)$ & $0(0)$ & $0(0)$ & - \\
\hline & Diplopia & $1(0.1)$ & $0(0)$ & $1(0.1)$ & 1.0000 \\
\hline & Ocular pain & $5(0.4)$ & $0(0)$ & $5(0.6)$ & 0.1652 \\
\hline & Decrease of visual acuity & $2(0.1)$ & $0(0)$ & $2(0.2)$ & 0.5358 \\
\hline & Other orbital symptoms & $2(0.1)$ & $0(0)$ & $2(0.2)$ & 0.5358 \\
\hline & Frontal symptoms & & & & \\
\hline & Total & $9(1.1)$ & $1(0.2)$ & $8(0.9)$ & $0.1673 \ddagger$ \\
\hline & Intense frontal pain & $9(0.7)$ & $1(0.2)$ & $8(0.9)$ & 0.1673 \\
\hline & Frontal oedema & $1(0.1)$ & $0(0)$ & $1(0.1)$ & 1.0000 \\
\hline & Neurological symptoms & $0(0)$ & $0(0)$ & $0(0)$ & - \\
\hline & Systemic symptoms & $0(0)$ & $0(0)$ & $0(0)$ & _ \\
\hline
\end{tabular}

${ }^{\star}$ Number of cases and proportion within group (\%).

$\dagger \chi^{2}$ test.

‡Fisher's exact test

prescribed in patients with severe ARS. On the other hand, the presence of symptoms linked to complications was not different between severity groups. Previous studies have reported the impact of ARS on QoL and its improvement with INS $^{37}$ or antibiotics ${ }^{14}$ using SNOT-20 and SNOT-16, respectively. In our study, postviral ARS had a higher impact on QoL than common cold but, in both groups, QoL improved and reached normal values no matter the treatment used for 2-4 weeks.

Although guidelines suggest that a diagnosis of bacterial ARS should be considered in patients with fever, severe unilateral pain, purulent rhinorrhoea and double sickening, ${ }^{38}$ there are real difficulties to differentiate between postviral and bacterial ARS. Several studies have reported an overuse of antibiotic prescriptions by PCPs. Dutch PCPs prescribed antibiotics in $34 \%$ of patients with moderate ARS, ${ }^{39}$ while US PCPs did so in $82.3 \%$ of ARS cases. ${ }^{40}$ In addition, ARS was behind $3.9 \%$ of all diagnoses with antibiotic prescription performed by PCPs. ${ }^{41}$ In our study, Spanish physicians prescribed antibiotics in most of the ARS cases either in common cold $(62 \%)$ or in postviral ARS (76\%). However, PCPs and ORLs overused the antibiotic prescription (53\% and 39\%, respectively). A potential explanation for this could be that PCPs may consider the term 'sinusitis' as a synonym of bacterial ARS, instead of being considered as an inflammatory condition. ${ }^{42}$

Current guidelines ${ }^{137}$ and recent systematic reviews ${ }^{20} 43$ recommend the use of oral antibiotics in combination with INS only in severe bacterial ARS or in complications, yet there are no indications for cases of mild to moderate non-complicated ARS. The potential benefit of antibiotics in treating ARS should be contrasted with the potential of inducing antibiotic resistance and the very low incidence of serious complications. ${ }^{19} 20$ Many recent studies have addressed the high costs of antibiotic resistance. ${ }^{41}$ de Kraker et $a l^{44}$ calculated the cost related to Staphylococcus aureus and Escherichia coli infections and their antibiotic resistance in Europe resulting in 8000 deaths and $€ 62$ million for 2007. Surprisingly, the incidence of infections by resistant bacteria was higher in countries with high use (ie, Portugal) compared with those with lower use (ie, Iceland or Norway) of antibiotics. Similarly, Carter $e t a l^{45}$ calculated the cost of infections produced by pandrug-resistant Gram-negative bacteria in the UK in an estimated 79000 deaths over a 20-year period. With regard to the role of antibiotics on preventing complications, Babar-Craig et at ${ }^{46}$ reported that complications requiring surgical intervention were 
Table 5 Risk factors for a viral rhinosinusitis leading to a postviral acute rhinosinusitis (ARS)

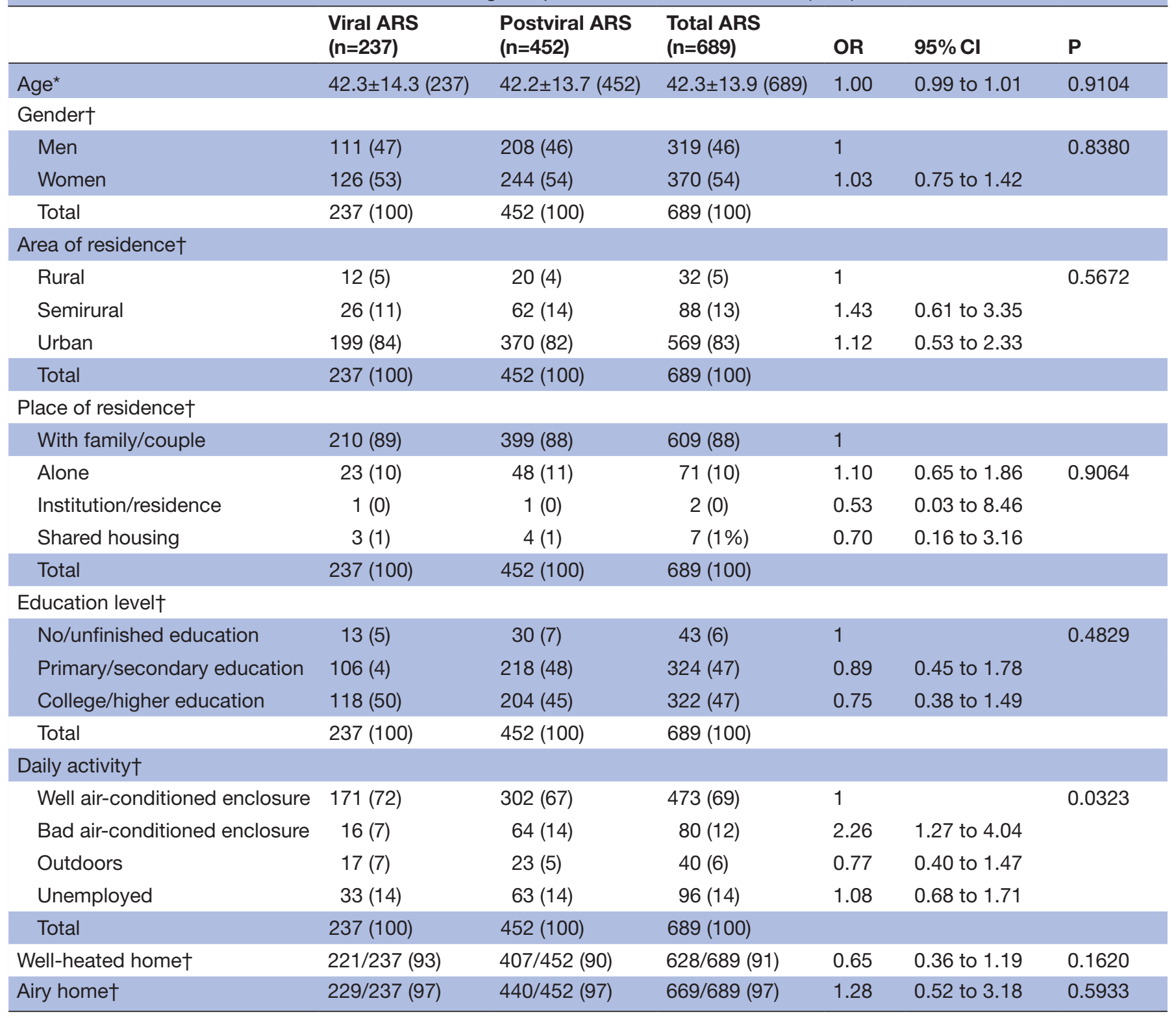

${ }^{*}$ Arithmetic mean \pm SD (n).

†Number of cases and proportion within group (\%).

similar in patients receiving antibiotic treatment or not. In the Netherlands, Hansen et $a l^{10}$ reported a very low rate of ARS complications in both children (1:12 000) and adult (1:32 000) patients, which suggested antibiotic treatment did not prevent complications. In our study, the frequency of symptoms suggesting complications was totally independent of the prescribed medication.

Although the efficacy of INS in ARS remains controversial, current guidelines ${ }^{1}$ and systematic reviews ${ }^{18} 47$ recommend the use of INS in moderate (monotherapy) and severe (in combination with antibiotics) ARS. Dolor et $a l^{17}$ first described that the addition of INS (fluticasone propionate) to antibiotic treatment improved clinical success rates and accelerated recovery. Further studies demonstrated the superiority of INS (mometasone furoate) in monotherapy over placebo and even over amoxicillin to improve nasal symptoms ${ }^{4849}$ and QoL ${ }^{37}$ in patients with moderate non-complicated ARS. However these benefits are only clear when INS is used in high doses and during almost 3 weeks. ${ }^{18} 48$ In common cold however INS is not related to better cure rates or symptom relief. ${ }^{50}$ In our study, Spanish physicians prescribe INS in two out of five $(38 \%)$ patients with common cold and in one out of two $(54 \%)$ patients with postviral ARS, with INS prescription being associated with a longer duration of the disease. As long as the present study is a reallife study, a cause-effect relationship cannot be stated (see the limitations of the study at the end of this section), since physicians may reserve INS treatment for cases with more prolonged disease. Some studies have described the efficacy of herbal medicines such as Myrtol, ${ }^{51}$ Pelargonium sidoides, ${ }^{52}$ and recently BNO $1016 .{ }^{53}$ In 2012, Pfaar et $a l^{54}$ reported that $C E$ added on to antibiotics reached a better symptom control 
of ARS compared with placebo. In consequence, the EPOS guidelines recommended their use in adult ARS. ${ }^{1}$ A recent meta-analysis by Kock $e t a t^{24}$ has confirmed the efficacy of some herbal compounds such as EPs 7630, Myrtol, BNO 101, BNO 1016, $C E$ and Esberitox. In the present study, an association was found between the use of $C E$ and a shorter disease duration, suggesting $C E$ be accepted by physicians as a treatment choice for ARS. In 2011 Wang et a $l^{27}$ published a study reporting a huge amount of medications prescribed in Asia to treat mild ARS (common cold). Over $80 \%$ of the general practitioners and ear, nose and throat (ENT) specialists prescribed at least one medication in ARS, with antihistamines (39.2\%) and nasal decongestants (33.6\%) being among the medications most frequently prescribed. Despite the fact that antihistamines and mucolytics have not shown any benefit on treating ARS, and are not recommended by international guidelines, ${ }^{1}$ physicians, and especially PCPs but also ENT specialists, in our study regularly prescribed antihistamines (26\%) and mucolytics (45\%) to patients with ARS.

In summary, the management of mild to moderate ARS is quite similar as for severe/bacterial ARS (apart from the need of antibiotics in specific cases) as disease can be expected to resolve even when moderate or severe symptoms are present. The use of INS appears to help resolution of the disease.

\section{Weaknesses and strengths}

As with all epidemiological studies, the PROSINUS survey may have some weaknesses and limitations. (1) The study population cannot be considered a random sample since there was no control over which patients received specific medications, or in which patients diagnostic tools were performed. We have attempted to address this by estimating regression models adjusted for the ARS type and severity level at visit 1 . In addition, the results have been interpreted in terms of association, avoiding any interpretation in terms of causality. (2) The management performed by PCPs (retrospective) and ORLs (prospective) cannot directly be compared since they were not parallel but consecutive groups with the same patients but assessed at different times. In addition, some unmet needs were identified in the study: clear validated criteria to define bacterial ARS and physicians' criteria to prescribing antibiotics.

On the other hand the following are the strengths of the study: (1) the high number of included patients, and that EPOS criteria were followed for inclusion criteria and to classify our patients' population; and (2) this is a real-life and prospective study providing physicians' real approach to the management of the disease in their daily clinical practice.

Although this study is based on data collected in 2007, ARS has not suffered significant changes in either available diagnostic tools or therapeutic options since then in Spain. In addition, overuse of antibiotics remains a significant burden for many diseases in our society. In consequence, we consider these findings very relevant for the current clinical practice.

\section{CONCLUSIONS}

To summarise our findings, despite the fact that consensus guidelines on ARS management have existed for more than a decade, a lot of diagnostic tools are still performed unnecessarily, and a lot of non-recommended medications are prescribed to treat a disease that is mostly self-limited. There is an important unmet need to educate physicians as much as policymakers to manage ARS following evidencebased clinical practice guideline recommendations. It has been proven that education is effective in reducing antibiotic prescriptions for respiratory tract infections ${ }^{55}$ and ARS. ${ }^{56}$ We found an overuse of diagnostic tools and prescribed medications but, in addition to the burden and mortality induced by antibiotic resistance due to antibiotic overuse, the associated direct and indirect costs remain to be analysed.

Acknowledgements The authors would like to thank all centres and specialists in otolaryngology from Spain who participated in the PROSINUS study.

Contributors FJM is the guarantor of the study, and has contributed to the conception and design of the study, literature search, acquisition of data, analysis and interpretation of data, and writing the manuscript. LQ has contributed to study design, acquisition of data, statistical analysis and interpretation of data, and drafting the manuscript and approving its final version. IA has contributed to literature research, interpretation of data, and drafting the manuscript and approving its final version. JM has contributed to the conception and design of the study, acquisition of data, analysis and interpretation of data, and critical reading of the manuscript and approving its final version.

Funding The PROSINUS study was partially sponsored by an unrestricted research grant from Hartington Pharmaceuticals.

Competing interests None declared.

Patient consent Obtained.

Ethics approval The ethics committee of our institution (Comité Étic de Investigació Clínica de l'Hospital Clínic de Barcelona: CEIC) approved the study (2006/3305).

Provenance and peer review Not commissioned; externally peer reviewed.

Data sharing statement The data sets generated during and/or analysed during the current study are available from the corresponding author on reasonable request.

Open Access This is an Open Access article distributed in accordance with the Creative Commons Attribution Non Commercial (CC BY-NC 4.0) license, which permits others to distribute, remix, adapt, build upon this work non-commercially, and license their derivative works on different terms, provided the original work is properly cited and the use is non-commercial. See: http://creativecommons.org/ licenses/by-nc/4.0/

(c) Article author(s) (or their employer(s) unless otherwise stated in the text of the article) 2018. All rights reserved. No commercial use is permitted unless otherwise expressly granted.

\section{REFERENCES}

1. Fokkens WJ, Lund VJ, Mullol J, et al. The European position paper on rhinosinusitis and nasal polyps 2012. Rhinology 2012;50(Suppl 23):1-299.

2. Klossek JM, Mesbah K. Presentation and treatment of acute maxillary sinusitis in general practice: a French observational study. Rhinology 2011:49:84-9.

3. Stjärne P, Odebäck P, Ställberg B, et al. High costs and burden of illness in acute rhinosinusitis: real-life treatment patterns and outcomes in Swedish primary care. Prim Care Respir J 2012;21:174-9.

4. Passioti M, Maggina P, Megremis S, et al. The common cold: potential for future prevention or cure. Curr Allergy Asthma Rep 2014;14:413. 
5. van Kempen M, Bachert C, Van Cauwenberge P. An update on the pathophysiology of rhinovirus upper respiratory tract infections. Rhinology 1999;37:97-103.

6. Berg O, Carenfelt C, Rystedt G, et al. Occurrence of asymptomatic sinusitis in common cold and other acute ENT-infections. Rhinology 1986;24:223-5.

7. Smith SS, Ference EH, Evans CT, et al. The prevalence of bacterial infection in acute rhinosinusitis: a Systematic review and metaanalysis. Laryngoscope 2015;125:57-69.

8. Epidemiology TRB. pathogenesis and treatment of the common cold. Ann Allergy Asthma Immunol 1997;78:531-40.

9. Oskarsson JP, Halldórsson S. [An evaluation of diagnosis and treatment of acute sinusitis at three health care centers]. Laeknabladid 2010;96:531-5.

10. Hansen FS, Hoffmans R, Georgalas C, et al. Complications of acute rhinosinusitis in The Netherlands. Fam Pract 2012;29:147-53.

11. Scadding G, Hellings P, Alobid I, et al. Diagnostic tools in Rhinology EAACI position paper. Clin Transl Allergy 2011;1:2.

12. Ebell MH, McKay B, Guilbault R, et al. Diagnosis of acute rhinosinusitis in primary care: a systematic review of test accuracy. Br J Gen Pract 2016;66:e612-e632.

13. Ahovuo-Saloranta A, Borisenko OV, Kovanen N, et al. Antibiotics for acute maxillary sinusitis. Cochrane Database Syst Rev 2008;16:CD000243.

14. Garbutt JM, Banister C, Spitznagel E, et al. Amoxicillin for acute rhinosinusitis: a randomized controlled trial. JAMA 2012;307:685-92.

15. Ahovuo-Saloranta A, Rautakorpi UM, Borisenko OV, et al. Antibiotics for acute maxillary sinusitis in adults. Cochrane Database Syst Rev 2014;11:CD000243.

16. Goossens H, Ferech M, Vander Stichele R, et al. Outpatient antibiotic use in Europe and association with resistance: a cross-national database study. Lancet 2005;365:579-87.

17. Dolor RJ, Witsell DL, Hellkamp AS, et al. Ceftin and Flonase for Sinusitis (CAFFS) Investigators. Comparison of cefuroxime with or without intranasal fluticasone for the treatment of rhinosinusitis. The CAFFS Trial: a randomized controlled trial. JAMA 2001;286:3097-105.

18. Hayward G, Heneghan C, Perera R, et al. Intranasal corticosteroids in management of acute sinusitis: a systematic review and metaanalysis. Ann Fam Med 2012;10:241-9.

19. Smith SR, Montgomery LG, Williams JW. Treatment of mild to moderate sinusitis. Arch Intern Med 2012;172:510-3.

20. Lemiengre MB, van Driel ML, Merenstein D, et al. Antibiotics for clinically diagnosed acute rhinosinusitis in adults. Cochrane Database Syst Rev 2012;10:CD006089.

21. Passali D, Loglisci M, Passali GC, et al. A prospective open-label study to assess the efficacy and safety of a herbal medicinal product (Sinupret) in patients with acute rhinosinusitis. ORL $J$ Otorhinolaryngol Relat Spec 2015;77:27-32.

22. Mullol J, Crespo C, Carré C, et al. Pharmacoeconomics of Cyclamen europaeum in the management of acute rhinosinusitis. Laryngoscope 2013;123:2620-5.

23. Ponikau JU, Hamilos DL, Barreto A, et al. An exploratory trial of Cyclamen europaeum extract for acute rhinosinusitis. Laryngoscope 2012;122:1887-92.

24. Koch AK, Klose P, Lauche R, et al. [A systematic review of phytotherapy for acute rhinosinusitis]. Forsch Komplementmed 2016;23:165-9.

25. Fokkens W, Lund V, Mullol J, et al. European position paper on rhinosinusitis and nasal polyps 2007. European Position Paper on Rhinosinusitis and Nasal Polyps group. Rhinology 2007:20:1-136.

26. Lim M, Lew-Gor S, Darby Y, et al. The relationship between subjective assessment instruments in chronic rhinosinusitis. Rhinology 2007;45:144-7.

27. Wang DY, Wardani RS, Singh K, et al. A survey on the management of acute rhinosinusitis among Asian physicians. Rhinology 2011;49:264-71.

28. van Gageldonk-Lafeber AB, van der Sande MA, Heijnen ML, et al. Risk factors for acute respiratory tract infections in general practitioner patients in The Netherlands: a case-control study. BMC Infect Dis 2007;7:35.

29. van Gageldonk-Lafeber AB, Heijnen M-LA, Bartelds AIM, et al. A case-control study of acute respiratory tract infection in general practice patients in The Netherlands. Clinical Infectious Diseases 2005;41:490-7.

30. Schatz M, Zeiger RS, Chen W, et al. The burden of rhinitis in a managed care organization. Ann Allergy Asthma Immunol 2008;101:240-7.
31. Zuskin E, Mustajbegovic J, Schachter EN, et al. Respiratory findings in mail carriers. Int Arch Occup Environ Health 2000;73:136-43.

32. Bonham GS, Wilson RW. Children's health in families with cigarette smokers. Am J Public Health 1981;71:290-3.

33. Jonas I, Mann W. [Misleading x-ray diagnosis due to maxillary sinus asymmetries (author's transl)]. Laryngol Rhinol Otol 1976;55:905-13.

34. McAlister WH, Lusk R, Muntz HR. Comparison of plain radiographs and coronal CT scans in infants and children with recurrent sinusitis. AJR Am J Roentgenol 1989;153:1259-64.

35. Bird J, Biggs TC, Thomas M, et al. Adult acute rhinosinusitis. BMJ 2013;346:f2687.

36. Gwaltney JM, Phillips CD, Miller RD, et al. Computed tomographic study of the common cold. N Engl J Med 1994;330:25-30.

37. Bachert C, Meltzer EO. Effect of mometasone furoate nasal spray on quality of life of patients with acute rhinosinusitis. Rhinology 2007;45:190-6.

38. Fokkens WJ, Hoffmans R, Thomas M. Avoid prescribing antibiotics in acute rhinosinusitis. BMJ 2014;349:g5703.

39. Hoffmans R, Schermer T, van Weel C, van WC, et al. Management of rhinosinusitis in Dutch general practice. Prim Care Respir J 2011;20:64-70.

40. Smith SS, Kern RC, Chandra RK, et al. Variations in antibiotic prescribing of acute rhinosinusitis in United States ambulatory settings. Otolaryngol Head Neck Surg 2013;148:852-9.

41. Smith SS, Evans CT, Tan BK, et al. National burden of antibiotic use for adult rhinosinusitis. J Allergy Clin Immunol 2013;132:1230-2.

42. Steurer J, Held U, Bachmann LM, et al. Clinical diagnosis of acute bacterial rhinosinusitis, typical of experts. J Eval Clin Pract 2009;15:614-9.

43. Sng WJ, Wang DY. Efficacy and side effects of antibiotics in the treatment of acute rhinosinusitis: a systematic review. Rhinology 2015;53:3-9.

44. de Kraker ME, Davey PG, Grundmann H. BURDEN study group. Mortality and hospital stay associated with resistant Staphylococcus aureus and Escherichia coli bacteremia: estimating the burden of antibiotic resistance in Europe. PLoS Med 2011;8:e1001104.

45. Carter D, Charlett A, Conti S, et al. A risk assessment of antibiotic pan-drug-resistance in the UK: Bayesian analysis of an expert elicitation study. Antibiotics 2017:6:9.

46. Babar-Craig H, Gupta Y, Lund VJ. British Rhinological Society audit of the role of antibiotics in complications of acute rhinosinusitis: a national prospective audit. Rhinology 2010;48:344-7.

47. Zalmanovici A, Yaphe J. Intranasal steroids for acute sinusitis. Cochrane Database Syst Rev 2009;4:CD005149.

48. Meltzer EO, Bachert $\mathrm{C}$, Staudinger $\mathrm{H}$. Treating acute rhinosinusitis: comparing efficacy and safety of mometasone furoate nasal spray, amoxicillin, and placebo. J Allergy Clin Immunol 2005;116:1289-95.

49. Keith PK, Dymek A, Pfaar O, et al. Fluticasone furoate nasal spray reduces symptoms of uncomplicated acute rhinosinusitis: a randomised placebo-controlled study. Prim Care Respir $J$ 2012;21:267-75

50. Hayward G, Thompson MJ, Perera R. et al Corticosteroids for the common cold. Cochrane Database Syst Rev 2012;15:CD008116.

51. Federspil P, Wulkow R, Zimmermann T. [Effects of standardized Myrtol in therapy of acute sinusitis--results of a doubleblind, randomized multicenter study compared with placebo]. Laryngorhinootologie 1997;76:23-7.

52. Timmer A, Günther J, Rücker G, et al. Pelargonium sidoides extract for acute respiratory tract infections. Cochrane Database Syst Rev 2008;3:CD006323.

53. Jund $\mathrm{R}$, Mondigler M, Stammer $\mathrm{H}$, et al. Herbal drug BNO 1016 is safe and effective in the treatment of acute viral rhinosinusitis. Acta Otolaryngol 2015;135:42-50.

54. Pfaar O, Mullol J, Anders C, et al. Cyclamen europaeum nasal spray, a novel phytotherapeutic product for the management of acute rhinosinusitis: a randomized double-blind, placebo-controlled trial. Rhinology 2012;50:37-44.

55. Little P, Stuart B, Francis N, et al. Effects of internet-based training on antibiotic prescribing rates for acute respiratory-tract infections: a multinational, cluster, randomised, factorial, controlled trial. Lancet 2013;382:1175-82

56. Gjelstad S, Høye S, Straand J, et al. Improving antibiotic prescribing in acute respiratory tract infections: cluster randomised trial from Norwegian general practice (prescription peer academic detailing (Rx-PAD) study). BMJ 2013;347:f4403. 